\title{
The Impact of Parental Behavior on the Cognitive Level of Preschoolers in Upper-Egypt
}

\author{
Dr. Rania Megally \\ Assistant Prof in Economics Independent Researcher, Egypt \\ Email: rania.megally@gmail.com \\ Dr. Rasha Aly Rashed \\ Economics Lecturer, London South Bank University, England \\ Email: alyr3@1sbu.ac.uk
}

Article History

Received: June 9, 2021

Revised: August 16, 2021

Accepted: August 20, 2021

Published: August 25, 2021

\author{
Prof. Dr. Hebatallah Ghoneim * \\ Associate Prof. of Economic Interim Head of Economic Department Faculty of Manage, German University in Cairo, \\ Egypt \\ Email: hebatallah.ghoneim@guc.edu.eg
}

\begin{abstract}
COVID-19 has reshaped our lives. Our houses turned into co-working areas, school classrooms, and playgrounds. Social distancing has put more weight on parents to ensure their children's education and cognitive gains. This has raised questions about the impact parents had on their children's cognitive levels even before COVID-19. This paper is an attempt to show how parents' behavior contributes to improving the cognitive level of their preschool children in a developing country. The paper also attempts to determine the relationship between parenting behavior and socioeconomic factors such as income and education.
\end{abstract}

Keywords: Cognitive skills; Parental behavior; Preschoolers.

\section{Introduction}

An evolving body of research has demonstrated the impacts of parental behaviours on their children's cognitive ability. This topic is particularly important in developing countries. Studies have proven that children raised in disadvantaged households show less cognitive and behavioural development as they reach school age (Heckman, 2006; Hobcraft and Kiernan, 2010; Kiernan and Huerta, 2008; Shonkoff and Phillips, 2000). These early gaps are highly persistent over time, with disadvantaged children having lower life-coping skills (Carneiro et al., 2005; Cunha et al., 2006; Feinstein, 2000; Neal and Johnson, 1996).

Parents' attitudes and parenting styles are influenced by their values and the expectations they have for their children's development, factors which in turn develop based on the parents' societal and cultural images as well as their experiences (Cabrera et al., 2011; Cheah and Chirkov, 2008; Iruka et al., 2015; Okagaki and Bingham, 2005; Rogoff, 2003; Rosenthal and Roer-Strier, 2006; Whiting and Whiting, 1975).

A study by Pougnet et al. (2011) surveyed a sample of 138 families involved in the Risk Project, an intergenerational longitudinal data set of families in Montreal, to investigate the effects of parental involvement on children's lives. The study found that fathers' positive parental control predicted higher performance IQ and made important contributions to their children's cognitive and behavioural functioning for both boys and girls, as well as resulted in less internalization of problems in preadolescence for girls. A variety of researchers, including Goodman (2001), Kucer (2009), and Larson and Marsh (2005), agree that children predominantly learn from the society surrounding them and that communication is an integral part of literacy learning. This is in line with Vygotsky's sociocultural theory, which suggests that knowledge is constructed by larger cultural systems (Scott and Palincsar, 2013).

Other parent-child relationship features have also been shown to affect cognitive and language outcomes in preschool children. Leiser et al. (2017), showed that the quality of the parent-child relationship played a significant role in the child's development, predicting $12 \%$ of the child's overall language and cognitive functioning. This result illustrates that reciprocal and harmonious parent-child interactions, evidenced by affective and/or verbal exchanges, help develop the child's cognitive and language abilities.

A variety of studies have concluded that children develop higher vocabulary skills if their fathers are more educated and communicate with them using varied and complex wording (Malin et al., 2012; Pancsofar and Vernon-Feagans, 2006; Rowe et al., 2016). Language development studies have found that posing a social context when communicating with children, such as asking more "where", "what" and "why" questions, in the early years of language development is highly linked with language acquisition (Baumwell et al., 1997; Bruner, 1983; Leech et al., 2013). This matches findings from experimental research on the impact of engaging children in discussion about readings rather than simply reading to them (Moe et al., 2008; Whitehurst et al., 1988). For example, Moe et al. 
found that discussing reading material enhanced children's vocabulary, an effect most pronounced in children aged 2-3 and more modest for children aged 4-5 and those at risk of language impairment.

Studies have also shown that book reading frequency develops not only language skills but also literacy (including syntax, grammar, and story structure) and affects children's success in reading, writing, and other areas (Baker, 2014; Duursma et al., 2008; Malin et al., 2014). Reading activities shared between parent and child also develop the child's knowledge of new words and help establish a sleeping routine (Isbell et al., 2004; Ninio, 1983; Whitehurst et al., 1988).

The effect of parenting on children's cognitive ability has been investigated in many empirical papers and in different parts of the world. However, little has been done to investigate the impact of parenting attitudes on the development of gross motor skills or non-cognitive skills. Thus, this study aims to develop a wider understanding of this impact by investigating the effects of parenting on both cognitive and non-cognitive abilities. Eight different models were used to investigate the impact on literacy level and fine, gross, and executive function motor levels, as well as attention level and overall cognitive level.

\section{Objectives}

This paper has two main objectives:

1. To overview the short- and long-term impacts of parental behaviors on children's performance; and

2. To measure the impact of parental behavior on the cognitive level of children in Upper Egypt.

\section{Methods}

This paper measures the impact of parental behaviour on the cognitive level of pre-schoolers using a crosssectional data set that covers around 4,500 children in the Upper-Egypt cities of Beni-Sweif, Maghagha, and ElMinia. The data is primary data collected in 2017.

The data were analysed using STATA 15.0. After obtaining descriptive statistics, the impact of parental behaviour on children's cognitive level was assessed, controlling for several explanatory variables, using multiple linear regression analysis.

\section{Sample}

The study covered 4,517 children and their parents. They were distributed throughout Upper Egypt, with a plurality in Beni-Suef (2,055 children) and the rest located in Maghagha and El-Minia (1,184 and 1,278 children, respectively). The gender distribution of the children was almost equally distributed between males and females, as shown in Figure 1 below: $52.65 \%$ of the children were boys and $47.35 \%$ girls. The children ranged in age from 2 years (approximately 4\%) to 7 years (approximately 28\%), with 3-, 4-, 5-, and 6-year-olds making up approximately $17 \%, 25 \%, 21 \%$, and $5 \%$ of the sample, respectively (shown in Figure 2 below).
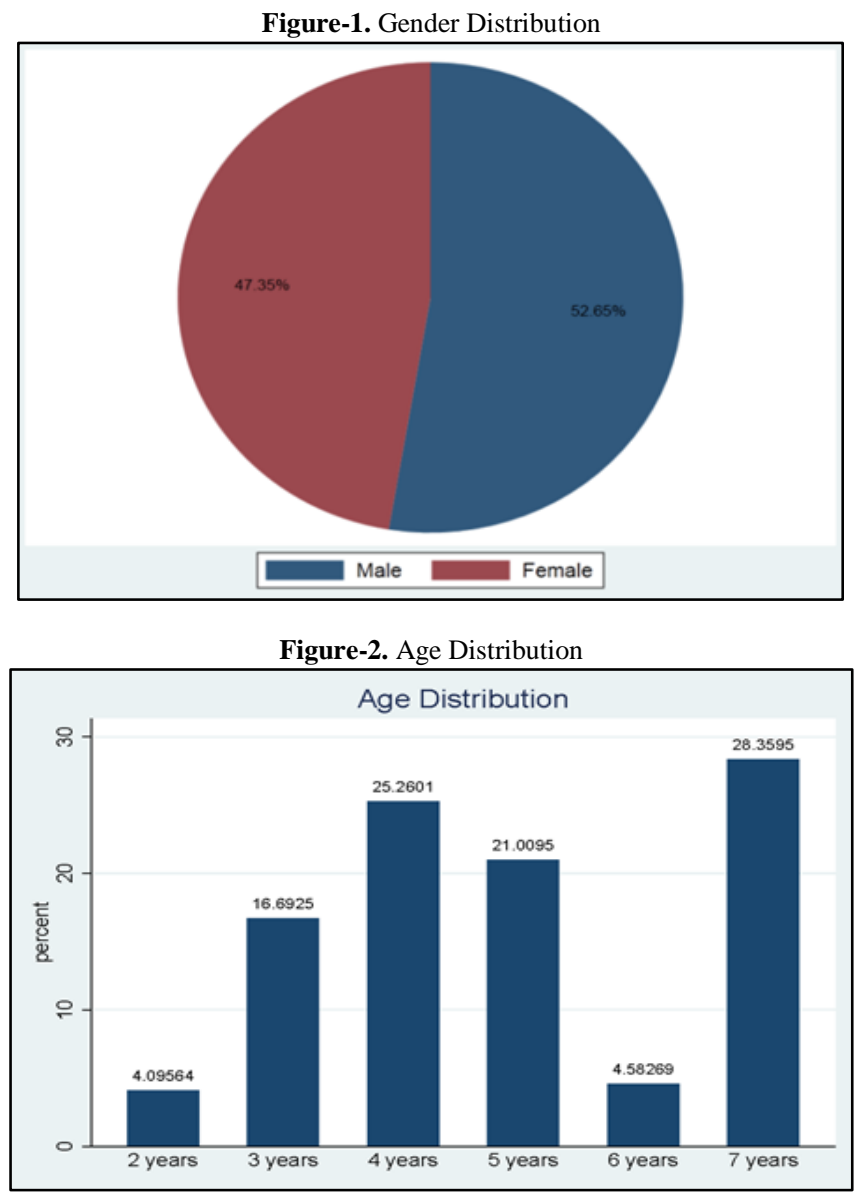
The family background of the children was measured by collecting information about the caregiver's educational level, the household income level, and the household's level of expenditure on food. According to the measurements, the majority of the caregivers had received vocational education, representing around $44 \%$ of the total sample. On the other hand, a fairly large percentage of parents were illiterate, representing around 33\%. The remaining caregivers' educational backgrounds varied from primary school to tertiary education level, in addition to a significant number who did not complete primary school but could read and write $(11 \%)$. In total, it can be reported that about $66 \%$ of caregivers were literate and only $33 \%$ illiterate, as visualized in Figure 3.

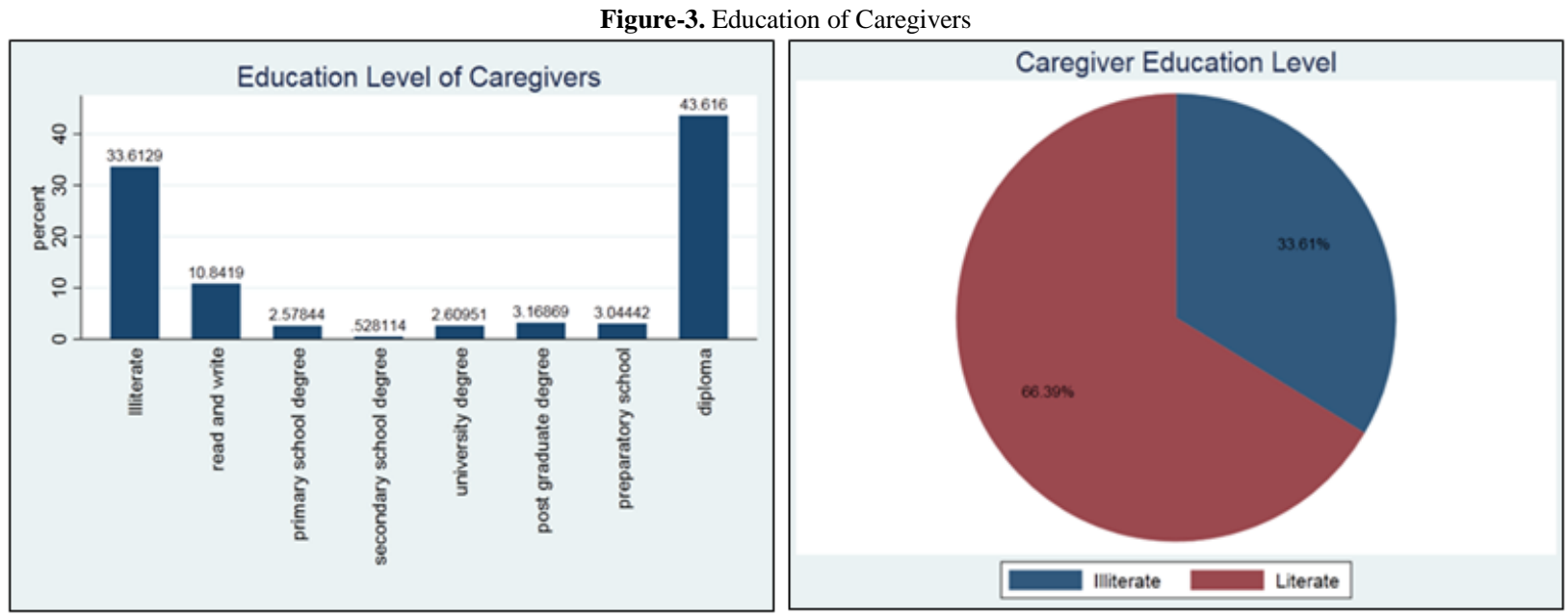

The income level of the breadwinners was measured based on their monthly income, categorized starting from less than 500 Egyptian Pounds (L.E.) a month to more than 5000 a month. As can be observed in Figure 4, the largest category, forming a majority of households, earned 500-1000 L.E. a month, followed by those earning 1000 1500 L.E. a month. A smaller percentage of households earned more than 1500 L.E., and only $15 \%$ earned less than 500 L.E.

Figure-4. Monthly Household Income in Egyptian Pounds

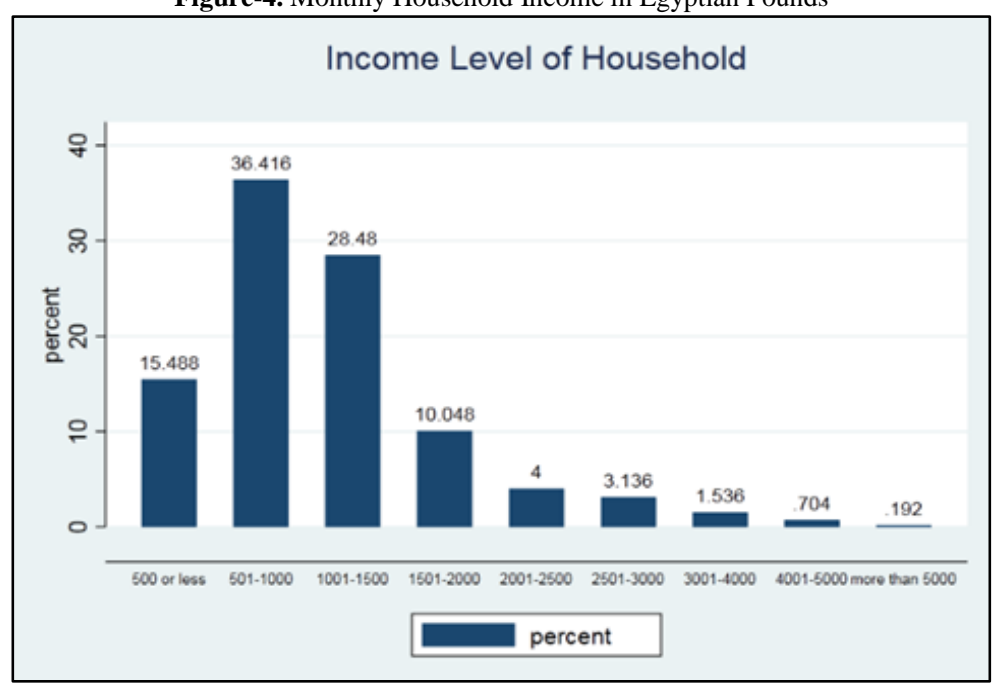

\section{Variables Definition}

The dependent and independent variables used in the data analysis are detailed in Table 1. The method of data collection is explained broadly in the following sub-section.

The dependent variable, cognitive development, was estimated using a Cognitive Test Scaled for Preschoolers. This is an individually administered instrument for assessing the level of intelligence of children three to seven years of age, but it can also be used with younger children. This scale consists of five groups of subtests. The first group assesses mathematics level and includes the subtests C3 (verbal counting), C4 (quantitative comparison), C5 (identification of numbers), and C6 (emerging numeracy). The second group of subtests assesses the literacy level and includes the subtests C12 (expressive vocabulary), C13 (identification of letters), and C23 (recognition of pictures). The third group of subtests assesses cognition level, or in other words, executive function. This is measured using subtests C19 (Head-Knees Task), C20 (backward Head-Knees Task), C21 (digit span), and C22 (backward digit span). The fourth group of subtests assesses fine motor skills using two drawing tasks, C8 (drawing of shapes) and C9 (drawing of a person). The fifth group consists of one subtest, C17 (gross motor skills). In addition, two new sections were added testing different skills: subtests C24 (memory) and C10 (cancellation, which assesses sustained attention). Concluding the scores of all subtests and groups are combined to yield the overall cognitive test score. 
Sumerianz Journal of Economics and Finance

Table-1. Summary of Subtests of the Cognitive Test Scaled for Pre-schoolers

\begin{tabular}{|c|c|c|}
\hline Dependent Variable & Subtest Content & \\
\hline C3 score & Mathematics counting & \multirow[t]{4}{*}{ Mathematics } \\
\hline C4 score & Quantitative comparisons & \\
\hline C5 score & Number identification & \\
\hline C6 score & Emerging numeracy & \\
\hline C8 score & Shapes drawing & \multirow[t]{2}{*}{ Fine motor skills } \\
\hline C9 score & Person drawing & \\
\hline C10 score & Sustained attention & Attention \\
\hline C12 score & Expressive vocabulary & \multirow[t]{3}{*}{ Literacy } \\
\hline C13 score & Letter identification & \\
\hline C23 score & Picture recognition & \\
\hline C17 score & Gross motor skills & Gross motor skills \\
\hline C19 score & Head-knees task & \multirow[t]{4}{*}{ Executive function } \\
\hline C20 score & Forward digit span & \\
\hline C21 score & Backward digit span & \\
\hline C22 score & Head-knees task, backward & \\
\hline C24 score & Memory skills & Memory \\
\hline Overall score & Total cognitive score & \\
\hline
\end{tabular}

The children's cognitive level was measured using the scores of all scales: mathematics, literacy, executive function skills, fine motor skills, gross motor skills, attention, and memory skills. We have calculated Cronbach's alpha in order to test the inter-item covariance or the inter-item correlations for all the cognitive level subgroups of all children except of the missing ones due to their absence during the data collection process. A higher $\alpha$ reflects a higher shared covariance between the items and is a measure of reliability. Cronbach's $\alpha$ was calculated to be 0.8838 , as shown in Table 2 below, which reflects high covariance of the items. This relatively high $\alpha$ value indicates that the items contribute to measuring the overall score of the cognitive level properly and thus can be relied on as a valid scale (Tavakol and Dennick, 2011). The cognitive level z-scores range from -2.4 to 2.6.

Table-2. Inter-Item Correlations for the Cognitive Level Subsets

\begin{tabular}{|c|c|c|c|c|c|c|}
\hline Item & Obs & Sign & $\begin{array}{c}\text { item-test } \\
\text { correlation }\end{array}$ & $\begin{array}{c}\text { item-rest } \\
\text { correlation }\end{array}$ & $\begin{array}{c}\text { average } \\
\text { interitem } \\
\text { covariance }\end{array}$ & alpha \\
\hline c1_math_sc $\sim e$ & 4517 & + & 0.8713 & 0.8198 & .3797688 & 0.8480 \\
\hline$c 1$ litt_sc ue & 4517 & + & 0.8518 & 0.7859 & .3758739 & 0.8528 \\
\hline c1_efuncti e & 4517 & + & 0.6953 & 0.6036 & .4343074 & 0.8710 \\
\hline cl_fmotor_ $\sim e$ & 3184 & + & 0.7778 & 0.6912 & .393651 & 0.8645 \\
\hline cl_gmotor_ $\sim e$ & 3184 & + & 0.7192 & 0.5896 & .3918831 & 0.8762 \\
\hline cl_attenti e & 4517 & + & 0.8187 & 0.7170 & .3722113 & 0.8693 \\
\hline c1_memory_ e & 3184 & + & 0.6641 & 0.5174 & .4067295 & 0.8849 \\
\hline Test scale & & & & & .3936153 & 0.8838 \\
\hline
\end{tabular}

The independent variables include the child's age and gender, the caregiver's education level and literacy level, the breadwinner's income level, and the parent's behavior with their children. The last of these is measured via the following questions, which address the frequency of a variety of attitudes and activities over the previous two weeks.

Table-3. Caregiver's Attitude and Behavior with the Child

\begin{tabular}{l|l}
\hline Independent Variable & Question \\
\hline Books & $\begin{array}{l}\text { How often did you read books/magazines or look at pictures in } \\
\text { books/magazines with your child? }\end{array}$ \\
\hline Punish & How often do you physically punish your child? \\
\hline Wordgames & How often do you PLAY GAMES WITH WORDS with your child? \\
\hline Anger & $\begin{array}{l}\text { When you feel angry, how often do you direct your anger at your child by } \\
\text { shouting at he/she? }\end{array}$ \\
\hline Stories & How often do you TELL STORIES to your child? \\
\hline Annoyed/annoyed1 & How often do you feel annoyed by what your child has done? \\
\hline Sing & How often do you SING SONGS with/to your child? \\
\hline NumberGames & $\begin{array}{l}\text { How often do you TALK with your child, for example naming objects, } \\
\text { describing daily routines, etc.? }\end{array}$ \\
\hline Annoyed_Cries/annoyed2 & How often do you PLAY GAMES WITH NUMBERS with your child? \\
\hline
\end{tabular}




\begin{tabular}{l|l}
\hline SelfIndependent/teach & $\begin{array}{l}\text { How often do you TEACH your child how to BECOME SELF- } \\
\text { SUFFICIENT IN DAILY ROUTINES, for example getting dressed, using } \\
\text { the bathroom, etc.? }\end{array}$ \\
\hline ActiveGames & $\begin{array}{l}\text { How often do you PLAY ACTIVE GAMES with your child, for example } \\
\text { playing with a ball, running, etc.? }\end{array}$ \\
\hline Walk & How often do you go for walks with your child? \\
\hline Talk_good/talk2 & $\begin{array}{l}\text { How often do you talk with your child when your child does something bad } \\
\text { or naughty? }\end{array}$ \\
\hline Paint & How often do you draw or paint with your child? \\
\hline Call_Lazy/callnames & How often did you call your child names like "dumb" or "lazy"? \\
\hline
\end{tabular}

\section{Ethics}

All procedures involving children were done on preschool premises. Parents, school principals, and teachers were given a detailed explanation of the study's aims and procedures. Parents had to sign or fingerprint a written consent form (see Appendix) and fill in the application. In addition, a training session was conducted for the teachers involved in the procedures, and the teachers were monitored for their performance during the treatment period and data collection.

\section{Regression Results: Estimating the Impact of Parental Behaviour on Cognitive Level}

We were interested in estimating the causal effect of parents' behaviour on the cognitive level of their young children in Upper Egypt. Parental behaviours were measured as explained in Table 3, and the impact on their children's cognitive level was measured both on each individual subgroup scale and on the overall cognitive level. The following outcomes equation for math ability is modelled as follows:

$$
Y_{i}=\beta_{o}+\beta_{1 \mathrm{i}} \text { NumGames }_{\mathrm{i}}+\beta_{2 \mathrm{i}} \text { SelfIndependent }_{\mathrm{i}}+\beta_{3 \mathrm{i}} \text { Age }_{\mathrm{i}}+\beta_{4 \mathrm{i}} \text { Gender }_{\mathrm{i}}+\beta_{5 \mathrm{i}} \text { Edu }_{\mathrm{i}}+\mathrm{u}_{\mathrm{i}}
$$

Where $Y_{i}$ is a continuous variable representing the math score, NumGames ${ }_{i}$ is a categorical variable representing the number of times in two weeks the caregiver played games with numbers, SelfIndependent $t_{i}$ is a categorical variable representing the number of times in two weeks the caregiver taught their child how to be selfindependent in daily routine activities, and $\mathrm{u}_{\mathrm{i}}$ refers to error term.

The results showed that the more frequently a caregiver played number games with their child, the higher the child's math score, with $P$-value less than $1 \%$. The same applies to the frequency of the caregiver teaching their child to become self-sufficient in daily routines: it also has a positive significant impact on the child's math score. In addition, the educational level of the caregiver has a positive significant impact on the math score, with a higher educational degree for the caregiver resulting in a higher math score for the child. Lastly, older children obtained higher math scores (as they did on all other scores).

The second model explains the impact of parental behaviour on the literacy level of the child as follows:

$$
\begin{gathered}
Y_{i}=\beta_{o}+\beta_{1 i} \text { WordGames }_{i}+\beta_{2 i} \text { Stories }_{i}+\beta_{3 i} \text { Sing }_{i}+\beta_{4 i} \text { Age }_{i}+\beta_{5 i} \text { Gender }_{i}+\beta_{6 i} \text { Income }_{i} \\
+u_{i}
\end{gathered}
$$

Where $Y_{i}$ is a continuous variable representing the literacy score, WordGames $_{i}$ is a categorical variable representing how many times in two weeks the caregiver played word games with their child, Stories $s_{i}$ is a categorical variable representing how many times in two weeks the caregiver told their child stories, Sing ${ }_{i}$ is a categorical variable representing how many times in two weeks the caregiver sang songs to their child, Income $\mathrm{i}_{\mathrm{i}}$ is a continuous variable representing the income level of the family breadwinner, and $\mathrm{u}_{\mathrm{i}}$ refers to error.

The results showed that the more frequently that the caregiver played word games with their child, the higher the child's literacy score was, with a $P$-value less than 5\%. Similarly, storytelling frequency had a significant positive impact on the literacy score of the child. However, a higher frequency of singing songs with the child instead had a significant negative impact on the child's literacy level. Finally, the income level of the caregiver had a significant positive impact on the child's literacy score.

The third model explains the impact of parental behaviour on the child's fine-motor skills as follows:

$$
Y_{i}=\beta_{o}+\beta_{1 i} \text { Paint }_{i}+\beta_{2 i} \text { Age }_{i}+\beta_{3 i} \text { Gender }_{i}+\beta_{4 i} \text { Edu }_{i}+\beta_{5 i} \text { Income }_{i}+u_{i}
$$

Where $Y_{i}$ is a continuous variable representing the fine-motor score and Paint $t_{i}$ is a categorical variable representing how many times in two weeks the caregiver painted with their child. The remaining variables are as explained in the previous models.

The results showed that the more frequently the caregiver painted with her child, the higher the child's finemotor skills score, with a $P$-value less than $5 \%$. However, the education level of the caregiver did not have any impact on the child's fine-motor skills, nor did the income level.

The fourth model explains the impact of parental behaviour on the child's gross-motor skills level as follows:

$$
Y_{i}=\beta_{o}+\beta_{1 i} \text { ActiveGames }_{i}+\beta_{2 i} A_{\text {Age }}+\beta_{3 i} \text { Edu }_{i}+u_{i}
$$

Where $Y_{i}$ is a continuous variable representing the gross-motor score and ActiveGames $s_{i}$ is a categorical variable representing how many times in two weeks the caregiver played active games with their child. The remaining variables are as explained in the previous models. 
The results showed that the frequency of active play had no impact on the child's gross-motor skills. The only variable that had a significant impact on the gross-motor score was the age: the older the child, the higher the grossmotor score.

The fifth model explains the impact of parental behaviour on the child's executive function level as follows:

$$
Y_{i}=\beta_{o}+\beta_{1 i} \text { Books }_{i}+\beta_{2 i} \text { Age }_{i}+\beta_{3 i} \text { Gender }_{i}+\beta_{4 i} \text { Edu }_{i}+u_{i} \ldots \ldots \ldots \ldots \ldots \ldots \ldots \ldots \ldots \ldots \text { (5) }
$$

Where $Y_{i}$ is a continuous variable representing the executive-function motor score and Books $s_{i}$ is a categorical variable representing how many times in two weeks the caregiver read books with their child. The remaining variables are as explained in the previous models.

The results showed that the more frequently the caregiver read books with their child, the higher the child's executive-function motor score was, with a $P$-value than $10 \%$. The education level of the caregiver had no impact on the child's executive function score.

The sixth model explains the impact of parental behaviour on the child's attention level as follows:

$$
Y_{i}=\beta_{o}+\beta_{1 i} \text { Anger }_{i}+\beta_{2 i} \text { Annoyed }_{i}+\beta_{3 i} \text { Talk }_{i}
$$

$+\beta_{4 \mathrm{i}}$ Annoyed_Cries $_{\mathrm{i}}++\beta_{5 \mathrm{i}}$ Talk_Good $_{\mathrm{i}}+\beta_{6 \mathrm{i}}$ Age $_{\mathrm{i}}+\beta_{7 \mathrm{i}}$ Gender $_{\mathrm{i}}+\beta_{8 \mathrm{i}}$ Literacy $_{\mathrm{i}}$

$$
+\beta_{9 i} \text { Income }_{i}+u_{i}
$$

Where $Y_{i}$ is a continuous variable representing the attention score, Anger ${ }_{i}$ is a categorical variable representing how many times in two weeks the caregiver got angry at their child, Annoyed $\mathrm{d}_{\mathrm{i}}$ is a categorical variable representing how many times in two weeks the caregiver got annoyed by mistakes committed by the child, Talk $\mathrm{i}_{\mathrm{i}}$ is a categorical variable representing how many times in two weeks the caregiver talked about objects and daily routines with their child, Annoyed_Cries $\mathrm{i}_{\mathrm{i}}$ is a categorical variable representing how many times in two weeks the caregiver got angry at their child when the child cried, and Talk_Good ${ }_{i}$ is a categorical variable representing how many times in two weeks the caregiver talked to their child when the child did something wrong. Literacy $y_{i}$ is a dummy variable, given a value of 1 if the caregiver was literate and 0 if the caregiver was illiterate. The remaining variables have been explained in the previous models.

The results showed that the more frequently the caregiver got angry at their child, the lower the child's attention score was, with a $P$-value less than $10 \%$. The frequency of talks about objects and daily routines also had significant negative impacts on attention level. On the other hand, talking with the child when they cried or did something wrong had significant positive impacts on the child's attention level. Lastly, the literacy level of the caregiver and

\begin{tabular}{|c|c|c|c|c|c|c|c|c|}
\hline & Depende & Variables & & & & & & \\
\hline Variable & Math & Literacy & $\overline{\text { F_Motor }}$ & G_Motor & E_Motor & Attention & Memory & Cognitive \\
\hline Books & & & & & $\begin{array}{l}0.0006^{*} \\
(0.0004)\end{array}$ & & & \\
\hline Punish & & & & & & & $\begin{array}{l}-0.0026^{*} \\
(0.0015) \\
\end{array}$ & \\
\hline Wordgames & & $\begin{array}{l}0.0014^{* *} \\
(0.0006)\end{array}$ & & & & & $\begin{array}{l}0.0016^{* *} \\
(0.0007)\end{array}$ & \\
\hline Anger & & & & & & $\begin{array}{l}-0.0020^{*} \\
(0.0010)\end{array}$ & $\begin{array}{l}-0.0026^{* *} \\
(0.0018)\end{array}$ & $\begin{array}{l}-0.0021^{* *} \\
(0.0008)\end{array}$ \\
\hline Stories & & $\begin{array}{l}0.0014^{* *} \\
(0.0006)\end{array}$ & & & & & & \\
\hline $\begin{array}{l}\text { Annoyed/ } \\
\text { annoyed } 1\end{array}$ & & & & & & $\begin{array}{l}0.0013 \\
(0.0013)\end{array}$ & $\begin{array}{l}0.0025^{*} \\
(0.0014)\end{array}$ & \\
\hline Sing & & $\begin{array}{l}-0.0019^{* * * *} \\
(0.0007)\end{array}$ & & & & & $\begin{array}{l}-0.0012 \\
(0.0008)\end{array}$ & \\
\hline $\begin{array}{l}\text { Talk_DailyRoutine } \\
\text { /talk }\end{array}$ & & & & & & $\begin{array}{l}-0.0016^{*} \\
(0.0008)\end{array}$ & & \\
\hline NumberGames & $\begin{array}{l}0.0012^{* * * *} \\
(0.0004)\end{array}$ & & & & & & & $\begin{array}{l}0.0004 \\
(0.0005)\end{array}$ \\
\hline $\begin{array}{l}\text { Annoyed_Cries } \\
\text { /annoyed2 }\end{array}$ & & & & & & $\begin{array}{l}0.0030^{* *} \\
(0.0012)\end{array}$ & & $\begin{array}{l}0.0019^{*} \\
(0.0010)\end{array}$ \\
\hline $\begin{array}{l}\text { SelfIndependent } \\
\text { /teach }\end{array}$ & $\begin{array}{l}0.0014^{* *} \\
(0.0007)\end{array}$ & & & & & & $\begin{array}{l}0.0025^{* *} \\
(0.0012)\end{array}$ & $\begin{array}{l}0.0017^{*} \\
(0.0010)\end{array}$ \\
\hline ActiveGames & & & & $\begin{array}{l}-0.0001 \\
(0.0005) \\
\end{array}$ & & & & \\
\hline $\begin{array}{l}\text { Talk_good } \\
\text { /talk2 }\end{array}$ & & & & & & $\begin{array}{l}0.0024^{* *} \\
(0.0011)\end{array}$ & & $\begin{array}{l}0.0022^{* *} \\
(0.0010)\end{array}$ \\
\hline Paint & & & $\begin{array}{l}0.0009^{* *} \\
(0.0004)\end{array}$ & & & & & \\
\hline Age & $\begin{array}{l}0.4631^{* * *} \\
(0.0153)\end{array}$ & $\begin{array}{l}0.4623^{* * * *} \\
(0.0194)\end{array}$ & $\begin{array}{l}0.4647^{* * * *} \\
(0.0175)\end{array}$ & $\begin{array}{l}0.3942^{* * * *} \\
(0.0203)\end{array}$ & $\begin{array}{l}0.3266^{* * *} \\
(0.0151)\end{array}$ & $\begin{array}{l}0.4463^{* * * *} \\
(0.0232)\end{array}$ & $\begin{array}{l}0.3302^{* * *} \\
(0.0248)\end{array}$ & $\begin{array}{l}0.6995^{* * * *} \\
(0.0199)\end{array}$ \\
\hline Gender & $\begin{array}{l}0.0497^{*} \\
(0.0295)\end{array}$ & $\begin{array}{l}0.0464 \\
(0.0370)\end{array}$ & $\begin{array}{l}0.1403^{* * *} \\
(0.0333)\end{array}$ & & $\begin{array}{l}0.0034 \\
(0.0290)\end{array}$ & $\begin{array}{l}0.1143^{* * * *} \\
(0.0439)\end{array}$ & & $\begin{array}{l}0.0911^{* *} \\
(0.0382)\end{array}$ \\
\hline Education Level & $\begin{array}{l}0.0036^{* *} \\
(0.0017)\end{array}$ & & $\begin{array}{l}0.0017 \\
(0.0019)\end{array}$ & $\begin{array}{l}-0.0004 \\
(0.0023) \\
\end{array}$ & $\begin{array}{l}0.0017 \\
(0.0017) \\
\end{array}$ & & & \\
\hline Literacy Level & & & & & & $\begin{array}{l}0.2421^{* * * *} \\
(0.0478)\end{array}$ & $\begin{array}{l}.0798 \\
(0.0514)\end{array}$ & $\begin{array}{l}0.2496^{* * *} \\
(0.0409) \\
\end{array}$ \\
\hline Income Level & & $\begin{array}{l}0.0001^{* *} \\
(0.0000)\end{array}$ & $\begin{array}{l}-0.0000 \\
(0.0000)\end{array}$ & & & $\begin{array}{l}0.0001^{* *} \\
(0.0000)\end{array}$ & $\begin{array}{l}0.0000 \\
(0.0000) \\
\end{array}$ & \\
\hline Obs & 2,119 & 1,704 & 1,651 & 2,059 & 2,119 & 1,693 & 1,640 & 2,106 \\
\hline $\mathrm{R}^{2}$ & 0.3066 & 0.2583 & 0.3121 & 0.1558 & 0.1821 & 0.1927 & 0.1101 & 0.3750 \\
\hline
\end{tabular}
the income level of the breadwinner both had significant positive impacts on the attention score.

Table-4. Estimated Impacts of Parental Behaviours on Cognitive Scales 
*** The coefficient is significant when $P$-value is less $<1 \%$

** The coefficient is significant when $P$-value is less $<5 \%$

* The coefficient is significant when $P$-value is less $<10 \%$

\section{Discussion}

No one can deny the importance of a parent's involvement in the development of their children. This paper attempts to highlight the most important variables that impact a child's cognitive skills. This paper not only investigates the impact on cognitive skills in an age range that has rarely been investigated, but also focuses on a developing country in an attempt to fill the gap for this neglected part of the world. Moreover, this sample concentrates on low-income households, with more than $99 \%$ of the involved families having an income of less than LE300 per month. Thus, the results of this study should help highlight the factors that could help low-income families improve their children's cognitive skills. It is, in short, an attempt to help children escape the poverty vicious circle.

This study examined the effect that parental behaviour, such as reading, painting, and playing with their children, and parental attitudes, such as anger, annoyance, and views on punishment, have on the cognitive behaviour of their children. The study also tested the impact of various socioeconomic factors, such as the parent's income and education and the child's age and gender. In this section, we will focus on some important implications raised by this quantitative study.

It is notable that a parent's education affects only their child's math ability, while parent literacy is positively correlated with the child's attention. These results fall in line with those of Martins and Veiga (2010), who investigated socioeconomic-related inequality in mathematics achievement in 15 European Union member states. Martins and Veiga concluded that differences in parental education did not explain the student achievement gap seen between countries. This is good news for developing countries that have high illiteracy rates: future generations can still gain cognitive skills despite the lower levels of education attained by their parents. Still, the results do show the need for literate parents who can read and write to support their children. Specially that based on the second model reading and playing word games have positive impact on children literacy. It is expected that those play word games and read are literate parents. Also, word game has significant positive impact on memories capabilities, while playing games has positive significant impact on cognitive skills. This emphasises the important role of programs that seek to support parents who cannot read or write.

In a developing country like Egypt, where nearly $24 \%$ of adult males and $29 \%$ of adult females are illiterate (according to World Bank (2017) data from 2017), adult education programs are of great importance. This fact is underscored by the government's adoption of "Fesoul Mahow Al-Omeya", or "classes to eliminate illiteracy." Unfortunately, these classes have used approaches that are not attractive to illiterates (Jalloul, 2012), and there is otherwise little interest in educating illiterate people (Hossam-Eldin, 2004). In order to ensure the effectiveness of these classes, the Ministry of Social Solidarity linked the benefits of "Takafoul and Karama", a cornerstone cash transfer program that assists low-income households, with illiteracy eradication under a program titled "No Illiteracy with Takafoul" (Helmy, 2020). This link between cash benefits and class attendance was meant to encourage parents to attend literacy classes and thereby contribute to creating a better future for their children.

That said, more important than a parent with a certificate is a parent who talks, plays, and paints with their children. Based on the regression analysis, playing word games, reading stories, teaching independence, and talking encouragingly all have a positive impact on children's cognitive skills. This implies that to help future generation escape the poverty vicious circle, it is important to teach parents methods of getting in touch with their children and employing skills that develop their children's cognitive skills. Establishing an early literacy environment at home and getting children engaged in learning with games and stories at preschool both play an important role in developing children's cognitive skills, an idea also supported by (Leyendeckera et al., 2011).

The regression analysis shows a significant impact of income on cognitive skills; however, it is very low. This falls in line with Gershoff et al. (2007), who stress that income is not enough to ensure children's cognitive development. What may give a better indication is not what parents earn but what they own. Blau (1999), showed that the impact of current income on child development is low, but Santos et al. (2008) demonstrated that low housing quality impacts the cognitive development of pre-schoolers. Regardless, income is not decisive. One factor that is much more important is the degree to which parents are patient and able to control their temper. This is clear from the significant negative correlation coefficient relating parents' behaviour, such as punishment and getting annoyed, with cognitive skills. This promotes the idea that positive parenting, a parenting philosophy that encourages parenting through kindness and support, is key to child cognitive development.

In short, an engaged family environment, where parents show interest and participate in developing their children's learning, is vital to cognitive development. This applies even under the adverse situation of low income: all parents have the chance to improve the lives of their children.

\section{Conclusions}

Early child development is crucial for sustainable development (Chan, 2013; Megally and Ghoneim, 2020). This paper shows that in order to ensure the development of cognitive skills in the early stages of child development, parental behavior should be emphasized. Programs are needed to ensure that parents are literate, supportive, and engaged in their children's learning process.

In an attempt to evaluate the impact of parents' behavior, this paper measured the cognitive skills of children aged 2 to 7 using seven different scales. In general, quantitative analysis showed that parents' behavior impacts the development of their children's cognitive skills, with the frequency of painting, reading, and playing number and 
word games having a positive impact on child's cognitive skills. Furthermore, a parent's patience, anger control, and attention to the child when the child cries also contribute to cognitive development.

\section{Acknowledgment}

The authors are grateful for the advice, support and help provided by the economics department at Manheim University. We gratefully acknowledge financial support from the Research Center (SFP) 884 "Political Economy of Reforms" funded by the German Research Foundation (DFG).

\section{References}

Baker, C. E. (2014). African American fathers' contributions to children's early academic achievement: Evidence from two-parent families from the early childhood longitudinal study-birth cohort. Early Education and Development, 25(1): 19-35.

Baumwell, L., Tamis-LeMonda, C. S. and Bornstein, M. H. (1997). Maternal verbal sensitivity and child language comprehension. Infant Behavior and Development, 20(2): 247-58.

Blau, D. M. (1999). The effect of income on child development. Review of Economics and Statistics, 81(2): 261-76.

Bruner, J. (1983). The acquisition of pragmatic commitments. In Golinkoff, R. M. (Ed.). (2013). The transition from prelinguistic to linguistic communication. Psychology Press: Hillsdale, NJ: Lawrence Erlbaum Associate. 27-42.

Cabrera, N. J., Hofferth, S. L. and Chae, S. (2011). Patterns and predictors of father-infant engagement across race/ethnic groups. Early Childhood Research Quarterly, 26(3): 365-75.

Carneiro, P., Heckman, J. J. and Masterov, D. V. (2005). Labor market discrimination and racial differences in premarket factors. The Journal of Law and Economics, 48(1): 1-39.

Chan, M. (2013). Linking child survival and child development for health, equity and sustainable development. The Lancet, 381(9877): 1514.

Cheah, C. S. and Chirkov, V. (2008). Parents' personal and cultural beliefs regarding young children: A crosscultural study of aboriginal and Euro-Canadian mothers. Journal of Cross-Cultural Psychology, 39(4): 40223.

Cunha, F., Heckman, J. J., Lochner, L. and Masterov, D. (2006). Interpreting the evidence on life cycle skill formation. In E. Hanushek \& F. Welch (Eds.), Handbook of the economics of education. Amsterdam: The Netherlands: North Holland.

Duursma, E., Augustyn, M. and Zuckerman, B. (2008). Reading aloud to children: The evidence. Archives of Disease in Childhood, 93(7): 554-57.

Feinstein, L. (2000). The relative economic importance of academic, psychological, and behavioural attributes developed in childhood (CEP discussion). Centre for Economic Performance: London, UK.

Gershoff, E. T., Aber, J. L., Raver, C. C. and Lennon, M. C. (2007). Income is not enough: Incorporating material hardship into models of income associations with parenting and child development. Child Development, 78(1): 70-95.

Goodman, Y. (2001). The development of initial literacy. In E. Cushman, E. R. Kintgen, B. M. Kroll and M. Rose (Eds.), Literacy: A critical sourcebook. Bedford/St. Martin's: Boston.

Heckman, J. J. (2006). Skill formation and the economics of investing in disadvantaged children. Science, 312(5782): 1900-02.

Helmy, I. (2020). Takaful and Karama: The path for solidarity and dignity. In Ghoneim H. (Ed.), Economic Reform in Egypt: Selected Topics. KSP Books: Istanbul.

Hobcraft, J. N. and Kiernan, K. E. (2010). Predictive factors from age 3 and infancy for poor child outcomes at age 5 relating to children's development, behaviour and health: Evidence from the millennium cohort study (Report). The University of York: York, UK.

Hossam-Eldin, S. (2004). Al-Taleim wa tahdiat al-moshkela al-sokania fee al-mogtamee al-masry Education and population problem challenges in the Egyptian society. Journal of Specific Education, 3: 31-150.

Iruka, I. U., Durden, T. and Kennel, P. (2015). Changing faces: Parenting, culture, and child learning and development. Zero to Three, 35(4): 10-18.

Isbell, R., Sobol, J., Lindauer, L. and Lowrance, A. (2004). The effects of storytelling and story reading on the oral language complexity and story comprehension of young children. Early Childhood Education Journal, 32(3): 157-63.

Jalloul, G., 2012. "The automation of illiteracy eradication and economic empowerment with computer based learning: An industry revolution perspective." In InSITE 2012: Informing Science+ IT Education Conference. pp. 265-79.

Kiernan, K. E. and Huerta, M. C. (2008). Economic deprivation, maternal depression, parenting and children's cognitive and emotional development in early childhood 1. The British Journal of Sociology, 59(4): 783806.

Kucer, S. (2009). Dimensions of Literacy: A conceptual base for teaching reading and writing in school settings. 3rd Ed. edn: Mahwah: NJ: Erlbaum.

Larson, J. and Marsh, J. (2005). Making literacy real: Theories and practices for learning and teaching. SAGE Publications Ltd: London, UK. 
Leech, K. A., Salo, V. C., Rowe, M. L. and Cabrera, N. J. (2013). Father input and child vocabulary development: The importance of wh-questions and clarification requests. Seminars in Speech and Language, NIH Public Access, 34(4): 249-59.

Leiser, K., Heffelfinger, A. and Kaugars, A. (2017). Associations among parent-child relationships and cognitive and language outcomes in a clinical sample of preschool children. The Clinical Neuropsychologist, 31(2): 423-37.

Leyendeckera, B., Jäkel, J., Kademoğlu, S. O. and Yagmurlu, B. (2011). Parenting practices and pre-schoolers' cognitive skills in turkish immigrant and german families. Early Child Development and Care, 181(8): 1095-110.

Malin, J. L., Cabrera, N. J., Karberg, E., Aldoney, D. and Rowe, M. L. (2014). Low-income, minority fathers' control strategies and their children's regulatory skills. Infant Mental Health Journal, 35(5): 462-72.

Malin, J. L., Karberg, E., Cabrera, N. J., Rowe, M., Cristaforo, T. and Tamis-LeMonda, C. S. (2012). Father-toddler communication in low-income families: The role of paternal education and depressive symptoms. Family Science, 3(3-4): 155-63.

Martins, L. and Veiga, P. (2010). Do inequalities in parents' education play an important role in PISA students' mathematics achievement test score disparities? Economics of Education Review, 29(6): 1016-33.

Megally, R. and Ghoneim, H. (2020). Evaluation of health intervention: a case of preschool children in Egypt. Palgrave Communications, 6(1): 1-8.

Moe, S. E., Bus, A. G., De Jong, M. T. and Smeets, D. J. (2008). Added value of dialogic parent-child book readings: A meta-analysis. Early Education and Development, 19(1): 7-26.

Neal, D. A. and Johnson, W. R. (1996). The role of premarket factors in black-white wage differences. Journal of political Economy, 104(5): 869-95.

Ninio, A. (1983). Joint book reading as a multiple vocabulary acquisition device. Developmental Psychology, 19(3): 445-51.

Okagaki, L. and Bingham, G. E. (2005). Parents' social cognitions and their parenting behaviors. In Luster T., Okagaki L (eds.), Parenting: An ecological perspective. Lawrence Erlbaum Associates: Mahwah, NJ.

Pancsofar, N. and Vernon-Feagans, L. (2006). Mother and father language input to young children: Contributions to later language development. Journal of Applied Developmental Psychology, 27(6): 571-87.

Pougnet, E., Serbin, L. A., Stack, D. M. and Schwartzman, A. E. (2011). Fathers' influence on children's cognitive and behavioural functioning: A longitudinal study of Canadian families. Canadian Journal of Behavioural Science/Revue Canadienne Des Sciences Du Comportement, 43(3): 173.

Rogoff, B. (2003). The cultural nature of human development. Oxford University Press: New York.

Rosenthal, M. K. and Roer-Strier, D. (2006). What sort of an adult would you like your child to be?: Mothers' developmental goals in different cultural communities in Israel. International Journal of Behavioral Development, 30(6): 517-28.

Rowe, M. L., Denmark, N., Harden, B. J. and Stapleton, L. M. (2016). The role of parent education and parenting knowledge in children's language and literacy skills among white, black, and Latino families. Infant and Child Development, 25(2): 198-220.

Santos, L. M. D., Santos, D. N. D., Bastos, A. C. S., Assis, A. M. O., Prado, M. S. and Barreto, M. L. (2008). Determinants of early cognitive development: hierarchical analysis of a longitudinal study. Cadernos de Saúde Pública, 24(2): 427-37.

Scott, S. and Palincsar, A. (2013). Sociocultural theory. The Gale Group. https://www.drhatfield.com/theorists/resources/sociocultural theory.pdf

Shonkoff, J. P. and Phillips, D. A. (2000). From neurons to neighborhoods: The science of early child development. National Academy Press: Washington, DC.

Tavakol, M. and Dennick, R. (2011). Making sense of cronbach's alpha. International Journal of Medical Education, 2: 53-55.

Whitehurst, G. J., Falco, F. L., Lonigan, C. J., Fischel, J. E., DeBaryshe, B. D., Valdez-Menchaca, M. C. and Caulfield, M. (1988). Accelerating language development through picture book reading. Developmental psychology, 24(4): 552.

Whiting, B. B. and Whiting, J. W. (1975). Children of six cultures: A psycho-cultural analysis. Harvard University Press: Cambridge, MA.

World Bank (2017). World development indicators. The World Bank. 